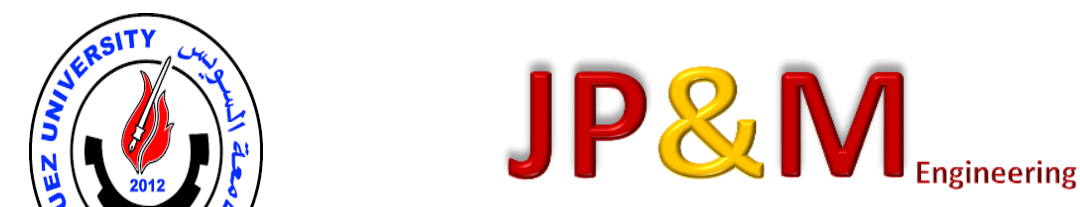

Journal of Petroleum and Mining Engineering

\title{
Production of Biodiesel from Used Cooking Using Linear Regression
}

\author{
Elgharbawy, A. S. ${ }^{a *}$, Sadik. W. A. ${ }^{\text {a }}$, Sadek, O. M. ${ }^{\text {a }}$, Kasaby, M. A. ${ }^{\text {a }}$ \\ ${ }^{a}$ Materials Science Department , Institute of Graduate Studies and Research (IGSR), Alexandria University, 163 Horrya Avenue, P.O. Box \\ 832, Shatby , 21526 Alexandria, Egypt. \\ Corresponding author*: Email: ab pet 88@hotmail.com
}

\section{Article Info \\ Received 14 Aug. 2020 \\ Revised 1 Sep. 2020 \\ Accepted 15 Sep. 2020}

\section{Keywords}

Biodiesel;

Linear regression; biodiesel specifications.

\begin{abstract}
Biodiesel represents a closed carbon dioxide cycle (approximately 78\%) because it is derived from renewable biomass sources. "Bio" means its biological and renewable source, and "diesel" represents its use as a fuel on diesel engines. Biodiesel is defined as "mono-alkyl esters of long chain fatty acids derived from vegetable oils and animal fats". The present study was carried out in order to identify an effective treatment of used cooking oil to get the ideal specification condition to obtain high yield of biodiesel and get the best conversion ratio of used cooking oil to biodiesel. The linear regression analysis concluded that methanol to oil ratio and catalyst concentration have a high positive statistical significant effect. Temperature has a positive statistical significant effect. The process time had a non statistical significant negative effect on the biodiesel yield and the mixing rate had a highly negative statistical significant effect. The best methyl ester conversion obtained was 99.2 wt.\% based on the following conditions : methanol to oil molar ratio of 7.54:1, catalyst concentration of $0.875 \%, 1.17 \mathrm{hr}$. of reaction time, temperature of $52{ }^{\circ} \mathrm{C}$, mixing rate $266 \mathrm{rpm}$.
\end{abstract}

\section{Introduction}

Biodiesel is a fatty acid alkyl ester which produced from biological sources such as vegetable oil, animal fats wastes and algae. Biodiesel produced from renewable resources is considered the most important biofuel[1]. The four types of the transesterification processes are as following: acidcatalyzed transesterification, alkaline catalyzed transesterification, enzyme catalyzed transesterification and non-catalyzed supercritical methanol. The alkaline catalyzed transesterification method was used in this work as it is the fastest reaction, higher yield, mild reaction condition, low cost, less corrosive, less toxicity. Transesterification is the process that organic group (alkyl) of an alcohol is substituted with the organic group of a triglyceride. Transesterification reactions are done with utilization of a catalyst either an acid or a base catalyst. Transesterification can be occurred by using of enzymes. Equation 1 shows the transesterification reaction.

\begin{tabular}{|c|c|c|c|c|}
\hline $\mathrm{H}_{2} \mathrm{C}-\mathrm{OCOR}$ & & & ROCOR' & $\mathrm{H}_{2} \mathrm{C}-\mathrm{OH}$ \\
\hline $\mathrm{H}_{2} \mathrm{C}-O \mathrm{OCOR}$ & $+3 \mathrm{ROH}$ & $\stackrel{\text { Catalyst }}{\rightleftarrows}$ & $\stackrel{+}{+}{ }^{+} O C O R^{\prime \prime}$ & $\mathrm{HC}-\mathrm{OH}$ \\
\hline $\mathrm{H}_{2} \mathrm{C}-\mathrm{OCOR}{ }^{\prime \prime \prime}$ & & & $\stackrel{+}{+}{ }^{+} O C O R^{\prime \prime \prime}$ & $\mathrm{H}_{2} \mathrm{C}-\mathrm{OH}$ \\
\hline Triglyceride & Alcohol & & Alkylester & Glycerol \\
\hline
\end{tabular}

Triglyceride is the mainly component of vegetable oils; it forms about $90-98 \%$ of total oil mass. Transesterification reaction occurs when the triglycerides react with an alcohol in specified time, temperature, mixing rate and in presence of catalyst producing a mixture of fatty acids alkyl esters (biodiesel) and glycerol[2, 3]. Methanol, ethanol or butanol are the mainly alcohols which can be used in transesterification reaction. Alkaline catalyzed transesterification steps are three major steps: the first step is feedstock treatment which includes measuring feedstock free fatty acid, removal of insoluble impurities and water removal[4]. The second step is the alkaline transesterification process which includes addition of alcohol and catalyst to the oil at specified temperature and mixing rate for certain time[5]. The final step of transesterification process is biodiesel treatment which includes biodiesel purification, water washing, and water removal from produced biodiesel[6]. There is many factors affecting biodiesel production, these factors are: methanol to oil ratio, catalyst concentration, temperature, time and mixing rate[7]. The effect of each factor on the final yield is studied in this work through using linear regression analysis as it allows usage of few numbers of experiments to cover wide range of variables. Linear regression method was used to analyze the results. Specifications of produced 
biodiesel are standard range and it can be blended with diesel engine $[8,9]$.

The statistical software Design Expert 6.0.7 (StatEase Inc., Minneapolis, USA) was used for design of experiments, regression, and graphical analyses of the data obtained. The triglycerides conversion to biodiesel reaches to $99.2 \%$. Freedman et al.[10] demonstrated that acid transesterification of soybean is occurred with reaction conditions: methanol to oil ratio is 30 , sulfuric acid is $1 \%$ at temperature $65^{\circ} \mathrm{C}$ and time is $69 \mathrm{~h}$ and the conclusion was the biodiesel conversion of $90 \%$. It was stated that acid transesterification of used cooking oil would need reaction conditions: methanol to oil ratio is 50 , sulfuric acid is $3.5 \%$ at temperature of $70{ }^{\circ} \mathrm{C}$. Guo et al.[11] concluded that heterogonous catalyst achieved yield is $95 \%$ with reaction conditions: methanol to oil ratio is 7.5 , sodium silicate as a catalyst is $3 \%$ at temperature $60^{\circ} \mathrm{C}$, time is 60 minutes and the mixing rate is $250 \mathrm{rpm}$.

\section{Materials and Methods}

\section{Materials Used in Experiments}

The oil had a percentage of water, solid particles that needed processing steps to be removed. The amount of oil was 20 litre with density $0.92 \mathrm{gm} / \mathrm{cm} 3$, the oil was viscous and dark color.

\section{Used cooking oil}

In Egypt, most of used cooking oils are thrown in sewages and the rest is land filled which is considered wasting a big wealth that can achieve a great profit so tending to use this feedstock will be an enormous towards biofuels industries. The feedstock (waste cooking oil) was obtained from home collections[1].

\section{Potassium Hydroxide}

The alkaline catalyst, which was anhydrous pure potassium hydroxide with purity $99 \%$.

\section{Methanol}

Methanol with purity $99.5 \%$ were purchased from Fluka Chemical Corporation. Precautions have to be considered during buying the chemicals and catalyst, as they should be free of water. Water is a big barrier to transesterification reaction to proceed. In addition, it lowers produced biodiesel yield and leads to soap formation.

\section{Equipment Used in Experiments}

The Equipment that were used in applying the experiments are the following:

- Magnetic heat stirrer employs a rotating magnetic field to motivate the spinning of the stir bar in the solution so the mixing of the reactants occurs in presence of heat supply so as the mixture reaches the desired temperature for the reaction.

- Conical flask for mixing reactants and handling products.

- Sensitive balance for weighing small amount of sample reached to $0.5 \mathrm{~g}$
- $\quad$ Burette for titration applications.

- Beakers to handle sample, reactant and catalyst.

- Condenser to cool hot vapours or liquids

- Separating funnel for separation of two liquid depending on difference in their densities.

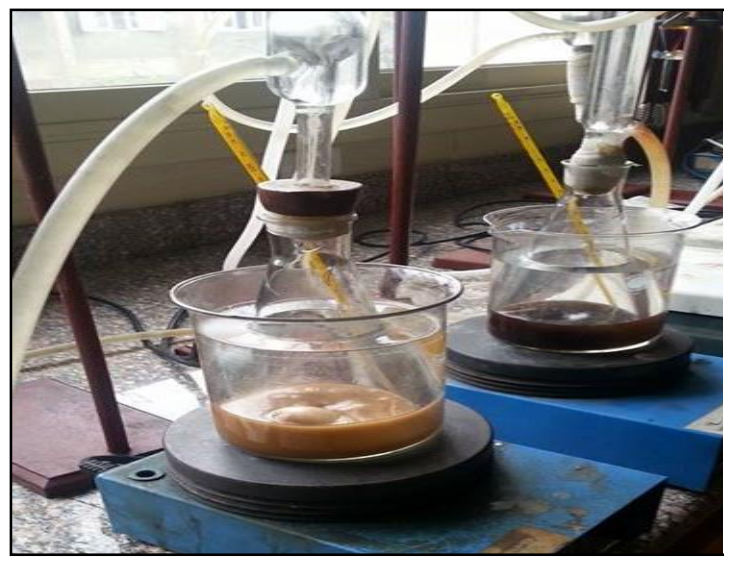

Figure 1. Equipments setup

\section{Method of Biodiesel Production}

\section{Feedstock Pre-treatment}

Waste cooking oil may contain high free fatty acid, water and other impurities which affect the final yield of biodiesel therefore treatment of feedstock is essential before transesterification step[12].

\section{Measuring Free Fatty Acid}

Free Fatty Acids (FFA) are undesirable compounds in feedstock or final biodiesel yield because of its noxious effects on yield quantity and specifications. In addition, it enhances backward reactions $[[9,13,14]$. The equation of measuring FFA\% in feedstock is:

$$
\mathrm{FFA} \%=\frac{(\mathrm{V}-\mathrm{b}) * \mathrm{~N} * 28.2}{\mathrm{~W}}
$$

Acid Number $($ AN $)=1.99 *$ FFA\%

Where,

- $\quad \mathrm{V}$ is the volume in $\mathrm{ml}$ of $\mathrm{KOH}$.

- $\quad \mathrm{N}$ is the normality of the $\mathrm{KOH}$.

- $\quad W$ is the weight of the sample of oil in grams.

By applying this equation on the used feedstock since:

$\mathrm{V}=1.95 \mathrm{ml}, \mathrm{b}=0.1 \mathrm{ml}, \mathrm{N}=0.1, \mathrm{~W}=1 \mathrm{gm}, \mathrm{FFA} \%=$ 0.522 and Acid Number $=1.04 \%$

This value refers that the feedstock does not need pretreatment transesterification, as the percentage of free fatty acid is less than $1 \%$.

\section{Removal of Solid Particles impurities}

The solid impurities in feedstock are particles of gravel, sand, bones, dirt, gum and any insoluble particles. This step is the first one of treatment processes. Feedstock is passed through a membrane filter with meshes size 100 micrometer so as to guarantee the removal of these particles from the feedstock.

\section{Water Removal}

The feedstock is heated to $105^{\circ} \mathrm{C}$ for an hour at atmospheric pressure to vaporize all water particles 
that probably be in oil. The alcohol methanol used in the transesterification reaction was with $99.5 \%$ purity and free of water. The catalyst potassium hydroxide was anhydrous. The feedstock is then cooled to $25^{\circ} \mathrm{C}$ or the ambient temperature before the transesterification process[14].

\section{Preparation of Alcohol and Catalyst}

Potassium hydroxide is a solid compound that do not dissolve easily into methanol. Methanol has to be agitated in the mixer firstly, then the catalyst is added slowly and carefully so dispersion of the potassium hydroxide in methanol is completed. Magnetic stirrer may be used to achieve better mixing of alcohol and catalyst[15].

\section{Alkaline Transesterification Process}

The transesterification reaction was carried out in $250 \mathrm{~mL}$ conical flask utilizing a magnetic heat stirrer. The flask equipped with a reflux condenser, thermometer for temperature monitoring. The conical flask with the attached equipment was immersed in a water bath, which was capable of maintaining the reaction temperature to within \pm $0.1^{\circ} \mathrm{C}$ of that required for the reaction temperature. Stirring velocity was adjusted at suitable $\mathrm{rpm}$ to ensure homogeneous mixing of the reactor mixture. After the oil reaches the required temperature for the reaction, the prepared mixture of potassium hydroxide and methanol is poured into the flask. When the reaction reaches the specified reaction time, the heating and stirring are then stopped. Separating funnel $500 \mathrm{~mL}$ is used for separation biodiesel from glycerol depending on significant difference in their densities[1, 16].

\section{Biodiesel Purification}

All the reaction products are poured in a separating funnel allowed to be settled over a night so as to guarantee a complete phase separation. Two liquid phases are formed during separation, the top phase is a crude biodiesel and its color is light yellow. The lower layer is a glycerol or a mixture of glycerol, catalyst and unreacted methanol and its color is black. The lower layer is removed from the bottom of the separating funnel[1].

\section{Water Washing}

The upper layer (crude biodiesel) is washed with warm distilled water at a temperature $50^{\circ} \mathrm{C}$ to remove the salts produced from the alkali transesterification process and the residual base catalyst. This process is repeated until the biodiesel layer become clear with neutral $\mathrm{pH}[1,17]$.

\section{Drying of Produced Biodiesel}

Biodiesel is then heating to $105^{\circ} \mathrm{C}$ for a half an hour to get rid of any unwanted water and unreacted methanol. This step makes biodiesel more clear and provide more purification to biodiesel. The obtained purified biodiesel is then poured in a well closed bottles so as not to expose to the air and be oxidized[18]. The yield of biodiesel from waste cooking oil (WCO) was calculated as shown in Eq 4.

$$
\% \text { Yield }=\quad \frac{\text { Weight of purified biodiesel }}{\text { Weight of WCO feedstock }} * 100
$$

\section{Experimental design}

In this study, the effects of five operating parameters including; Methanol: Oil M:O molar ratio (A), catalyst concentration wt\% (w:v, B), operating temperature ${ }^{\circ} \mathrm{C}(\mathrm{C})$, operating period is $\mathrm{hr}$. (D), and mixing rate $\mathrm{rpm}(\mathrm{E})$. All these parameters were investigated to maximize the biodiesel yield throughout the transesterification of waste cooking oil (WCO). The total number of experiments was 26 runs that included 11 factorial points which would allow the estimation of all the main effects and 10 axial points would allow the determination of all the quadratic terms.. The statistical software Design Expert 6.0.7 (Stat-Ease Inc., Minneapolis, USA) was used for design of experiments, regression and graphical analyses of the data obtained, doing the statistical analyses of the model and determine the significance levels of different parameters by evaluation of the analysis of variance (ANOVA), and it was also used for the optimization of the transesterification process.

Table 1: Experimental design

\begin{tabular}{|c|c|c|c|c|c|}
\hline & X1 & X2 & $\times 3$ & X4 & $\times 5$ \\
\hline $\begin{array}{c}\mathrm{Ru} \\
\mathrm{n}\end{array}$ & A:M:O & $\begin{array}{c}\text { B:Catal } \\
\text { yst }\end{array}$ & $\begin{array}{c}\text { C:Tempera } \\
\text { ture }\end{array}$ & $\begin{array}{l}\mathrm{D}: \mathrm{Ti} \\
\mathrm{me}\end{array}$ & $\begin{array}{c}\text { E:Mixi } \\
\text { ng } \\
\text { rate }\end{array}$ \\
\hline & $\begin{array}{c}\text { Molarr } \\
\text { atio }\end{array}$ & Wt \% & ${ }^{\circ} \mathrm{C}$ & $\mathrm{Hr}$. & Rpm \\
\hline & $\mathrm{X} 1$ & $\mathrm{X} 2$ & X3 & X4 & $\times 5$ \\
\hline 1 & 6 & 0.6 & 60 & 2 & 300 \\
\hline 2 & 6 & 1.15 & 60 & 2 & 300 \\
\hline 3 & 3 & 0.3 & 70 & 3 & 400 \\
\hline 4 & 9 & 0.3 & 70 & 1 & 400 \\
\hline 5 & 6 & 0.6 & 60 & 2 & $\begin{array}{c}482.1 \\
2\end{array}$ \\
\hline 6 & 6 & 0.6 & 78.21 & 2 & 300 \\
\hline 7 & 6 & 0.6 & 60 & 0.18 & 300 \\
\hline 8 & 6 & 0.6 & 60 & 2 & 117 \\
\hline 9 & 6 & 0.6 & 60 & 2 & 300 \\
\hline 10 & 3 & 0.9 & 70 & 1 & 400 \\
\hline 11 & 3 & 0.9 & 70 & 3 & 200 \\
\hline 12 & 3 & 0.9 & 50 & 3 & 400 \\
\hline 13 & 9 & 0.9 & 50 & 3 & 200 \\
\hline 14 & 9 & 0.3 & 70 & 3 & 400 \\
\hline 15 & 9 & 0.3 & 50 & 3 & 300 \\
\hline 16 & 9 & 0.9 & 70 & 1 & 400 \\
\hline 17 & 6 & 0.6 & 60 & 2 & 300 \\
\hline 18 & 9 & 0.9 & 50 & 1 & 300 \\
\hline 19 & 6 & 0.6 & 60 & 3.82 & 300 \\
\hline 20 & 6 & 0.6 & 41.79 & 2 & 300 \\
\hline 21 & 6 & 0.6 & 60 & 2 & 300 \\
\hline 22 & 11.5 & 0.6 & 60 & 2 & 300 \\
\hline 23 & 0.54 & 0.6 & 60 & 2 & 300 \\
\hline
\end{tabular}

\section{Results}

It is necessary to get specification of feedstock before reaction to decide the necessity of pretreatment needed to improve the specifications of feedstock to satisfied conditions. The feedstock oil in this work was used one time during domestic cooking for an hour at a temperature reached to $150^{\circ} \mathrm{C}$. The 
specification of waste cooking oil used in experiment is described in table 2 .

Table 2: Feedstock specifications

\begin{tabular}{|l|l|l|l|}
\hline Property & Units & Ref & Value \\
\hline Density & $\mathrm{gm} / \mathrm{cm}^{3}$ & $\begin{array}{l}\text { ASTM- } \\
4052\end{array}$ & 0.934 \\
\hline FFA & $\%$ & $\begin{array}{l}\text { ASTM- } \\
6584\end{array}$ & 0.522 \\
\hline Acid Value & $\mathrm{mg} \mathrm{KOH/g}$ & $\begin{array}{l}\text { ASTM- } \\
664\end{array}$ & 1.04 \\
\hline
\end{tabular}

\section{Yield of Experiment}

The yields of 26 experiments are shown in table 3 . Linear Regression Analysis

Regression analysis utilization is used for prediction and expectation the response (biodiesel yield) at any conditions and different factors without doing the related experiment by compensation in an equation called regression equation. It also helps the researchers to understand the way that the value of the response or the yield changes when any factor changes, while others factors are held fixed. Regression analysis evaluates the significance of each factor and determines if the individual factor is extremely affecting the final yield or not effecting. Statistical analysis of the model was applied to evaluate the analysis of variance (ANOVA). Linear regression analysis is done by Minitab,Inc 16 software for experimental design and data analysis. The estimation target is an equation of both important and non important factors. The linear regression equation is:

$y_{i}=\beta_{1} x_{i 1}+\beta_{2} x_{i 2}+\ldots+\beta_{p} x_{i p}+\ldots+\beta_{p} x_{i p}+\varepsilon_{i}$

Where $x i j$ is the factor on the jth independent variable, (so $\beta_{1}$ is the constant of variable).

The normal equations are:

$\sum_{i=1}^{n} \sum_{k=1}^{P} X_{i j} x_{i k} \beta_{k}=\sum_{i=1}^{n} X_{i j} y_{i}, \quad j=1 \ldots$.

The experimental yield is the real yield resulted from applying the different reaction conditions while the predicted is resulted from inserting reaction conditions in the Minitab.

The goal of the regression analysis is to obtain the regression model equation, specify the significance of each variable, and determine the optimum factors which achieve the highest yield. $R^{2}$ is a coefficient in regression analysis that demonstrates the fitting of model, as $R^{2}$ is closer to unity, the regression model is more fitting. The value of $R^{2}$ at this model was found to be 0.467 . This value ensures the moderate fitting and confirming the adequacy of the regression model. The linear regression equation is:

Biodiesel $\quad 60.6+1.94 * \mathrm{M}: 0+11.3 *$ Catalyst+

yield $=0.171 *$ Temperature-1.42*Time-

(Eq 6)
Table 3: biodiesel yield

\begin{tabular}{|c|c|c|c|}
\hline \multirow{2}{*}{$\begin{array}{c}\text { Run } \\
\text { number }\end{array}$} & \multicolumn{2}{|c|}{ Biodiesel yield (gm) } & \multirow{2}{*}{ Residual } \\
\hline & Experimental & Predicted & \\
\hline 1 & 85.6 & 79.02 & 6.58 \\
\hline 2 & 91.8 & 85.235 & 6.565 \\
\hline 3 & 64.4 & 69.81 & -5.41 \\
\hline 4 & 82.2 & 81.45 & 0.75 \\
\hline 5 & 70.5 & 79.02 & -8.52 \\
\hline 6 & 76.7 & 79.02 & -2.32 \\
\hline 7 & 80.5 & 79.02 & 1.48 \\
\hline 8 & 95.5 & 79.02 & 16.48 \\
\hline 9 & 85.5 & 79.02 & 6.48 \\
\hline 10 & 73.0 & 76.59 & -3.59 \\
\hline 11 & 70.5 & 76.59 & -6.09 \\
\hline 12 & 70.0 & 76.59 & -6.59 \\
\hline 13 & 78.0 & 88.23 & -10.23 \\
\hline 14 & 82.4 & 81.45 & 0.95 \\
\hline 15 & 78.9 & 81.45 & -2.55 \\
\hline 16 & 84.5 & 88.23 & -3.73 \\
\hline 17 & 85.5 & 79.02 & 6.48 \\
\hline 18 & 78.5 & 88.23 & -9.73 \\
\hline 19 & 78.4 & 79.02 & -0.62 \\
\hline 20 & 69.9 & 79.02 & -9.12 \\
\hline 21 & 85.5 & 79.02 & 6.48 \\
\hline 22 & 87.5 & 89.6 & -2.1 \\
\hline 23 & 62.8 & 68.42 & -5.62 \\
\hline 24 & 85.8 & 79.02 & 6.78 \\
\hline 25 & 58.5 & 72.805 & -14.305 \\
\hline 26 & 73.0 & 69.81 & 3.19 \\
\hline
\end{tabular}

\section{Residual Plots for Actual Yield (g)}

Regression Analysis: Actual Yield (g) versus M:O;

Catalyst; ...

The regression equation is

Biodiesel yield $=60.6+1.94 \mathrm{M}: 0+11.3$ Catalyst +0.171

Temperature -1.42 Time -0.0276 Mixing rate

Predictor Coef SE Coef $T \quad P$

$\begin{array}{lllll}\text { Constant } & 60.59 & 14.09 & 4.30 & 0.000\end{array}$

$\begin{array}{lllll}\text { M:O } & 1.9408 & 0.5914 & 3.28 & 0.004\end{array}$

$\begin{array}{lllll}\text { Catalyst } & 11.337 & 5.903 & 1.92 & 0.069\end{array}$

Temperature $0.1712 \quad 0.1804 \quad 0.95 \quad 0.354$

$\begin{array}{lllll}\text { Time } & -1.420 & 1.794 & -0.79 & 0.438\end{array}$

$\begin{array}{lllll}\text { Mixing rate } & -0.027 & 0.019 & -1.47 & 0.158\end{array}$

\section{$S=7.39120$}

Figure 2. The analysis of experiments by Minitab

The significance of each factor is determined by $\mathrm{P}$ values as shown in table 4 . If the $P$-value of one factor is less than 0.05, the factor becomes highly significant. If the P-value of one factor is near to 0.05 , the factor becomes significant. P-value of one factor is more than 0.05 , the factor is not significant. The factors with the highly significance is only M:O molar ratio. 
Catalyst concentration is significant to the final yield. The other factors such as time, temperature, and mixing rate are insignificant for the yield produced.

Table 4: Analysis of variance of the linear regression model

\begin{tabular}{|l|c|c|c|c|}
\hline & $\begin{array}{c}\text { Coeffici } \\
\text { ent }\end{array}$ & P-value & Status & Remarks \\
\hline M:O & 1.94 & 0.004 & $<0.05$ & $\begin{array}{c}\text { High } \\
\text { significant }\end{array}$ \\
\hline Catalyst & 11.3 & 0.069 & $\approx 0.05$ & $\begin{array}{c}\text { Statistically } \\
\text { Significant }\end{array}$ \\
\hline $\begin{array}{l}\text { Temper } \\
\text { ature }\end{array}$ & 0.171 & 0.354 & $0.05<$ & $\begin{array}{c}\text { Non } \\
\text { Statistically } \\
\text { Significant }\end{array}$ \\
\hline Time & -1.42 & 0.438 & $0.05<$ & $\begin{array}{c}\text { Non } \\
\text { Statistically } \\
\text { Significant }\end{array}$ \\
\hline $\begin{array}{l}\text { Mixing } \\
\text { rate }\end{array}$ & -0.037 & 0.158 & $0.05<$ & $\begin{array}{c}\text { Non } \\
\text { statistically } \\
\text { significant }\end{array}$ \\
\hline
\end{tabular}

Fig 2 indicates that the data is moderately fitted with the model giving a good estimation of response for the design overall the ranges which are studied. Residual is the difference between the experimental and predicted response. Fig 3 shows the relation between residuals against predicted response and it shows that the actual values within red points are nearly to the lines, which represent the predicted values confirming a good fit of experimental results.

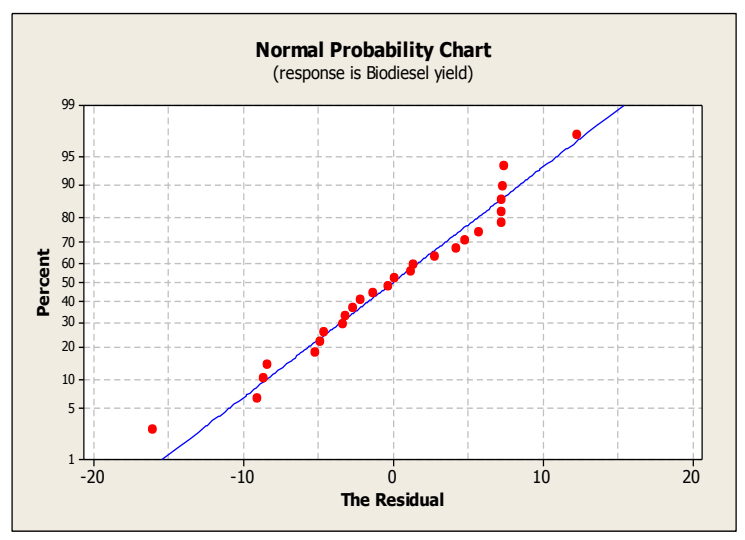

Figure 3. The relation between the experimental and predicted response

The significance of each factor is shown in Table 4. The Importance and effect of each factor is being explained and studied in details.

\section{Effect of Methanol to Oil Ratio}

Methanol is an important reactant as it merges with triglyceride to produce methyl ester (biodiesel). As per literature review excess amount of methanol will not be significant and after certain percentage more methanol will not affect the final yield or properties of biodiesel in contrast it will increase cost on the process as more purification steps will be required. Recovery of excess methanol consumes more equipment and power. Producing one mole of fatty acid methyl ester (biodiesel) requires three mole of methanol with one mole of triglyceride for the reaction to occur so when the molar ratio of alcohol to oil is lower than 3:1, the reaction will not occur or give poor results. High methanol percentage will increase glycerol product which draw back the reaction resulting in lower biodiesel yield. Presence of methanol in the final yield is not desirable as $1 \%$ wt of methanol in the produced biodiesel can lower the flashpoint of the biodiesel from 170 o $C$ to less than 40 ㄷ [44]. Molar ratio should be maintained in suitable range neither lower than 3 nor higher than 9 . Fig 4 shows that methanol to oil ratio optimum value around 6 to 9 beyond this value no significant effect on final yield. All experiments that have high methanol to oil ratio and reasonable values of other factors exhibit high yield so biodiesel yield is directly proportional to $\mathrm{M}: \mathrm{O}$ ratio and as shown in table 4 the effect of $M: O$ is high significant for the reaction as $p$ value is 0.004. Experiments which M:O ranges from 6 to 9 show the highest yield while Experiments that have lowest methanol to oil ratio show a minimum yield.

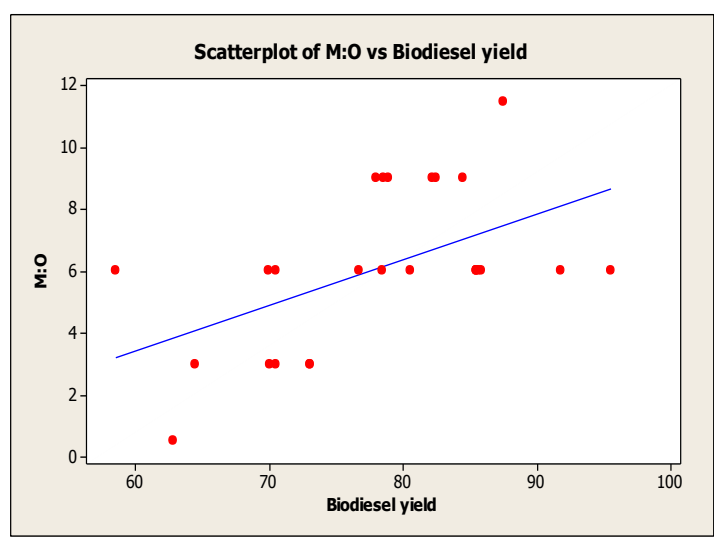

Figure 4. The relation between $\mathrm{M}: \mathrm{O}$ ratio and yield

\section{Effect of Catalyst}

Catalyst is a substance required to increase the reaction speed and it is not consumed during reaction. In absence of catalyst conversion of waste cooking oil in biodiesel requires high temperature conditions and long time [44]. The catalyst used was anhydrous potassium hydroxide ( $\mathrm{KOH})$. Increasing catalyst weight will increase biodiesel yield and improve its properties but to limited percentage as increasing beyond this limit will affect reversible on final yield and its properties. Excess amount of catalyst lead to soap formation, lower biodiesel yield and harms properties of biodiesel produced, in contrast low catalyst concentration slow the reaction and decrease produced yield in certain time. Low catalyst concentration will be compensated by high temperature and long time. Fig 5 shows that the optimum catalyst concentration value will be around $0.6 \%-0.9 \%$ beyond this value no significant effect on final yield.

\section{Effect of Temperature}

Reaction temperature is necessary to increase reaction rate but the temperature of reaction is 
preferred to be lower than the temperature at which the methanol boils which is $65^{\circ} \mathrm{C}$, so if the reaction temperature is higher than boiling point of methanol, methanol will evaporate so reaction will lose one of the reactants and reaction will be affected negatively, so biodiesel will decrease in addition production cost will be higher. The temperature of reaction should not be too high as discussed previously or too low as any reactant needs heat to activate its molecule to colloid with other molecules. Fig 6 shows that the optimum reaction temperature value will be around 50 to $60^{\circ} \mathrm{C}$. Temperatures except within range will not give significant yield. The relation between temperature and final yield in proportional as temperature increases, final yield increases. Experiments show the highest yield in all experiments and its temperature as shown in table 3 ranges around $60{ }^{\circ} \mathrm{C}$. Experiments have the lowest temperatures giving low yields and this proves that decreasing temperature lower than $50{ }^{\circ} \mathrm{C}$ decreases the yield. Experiments have reaction temperature $70^{\circ} \mathrm{C}$ which is higher than boiling point of methanol and in this regards yield produced becomes low.

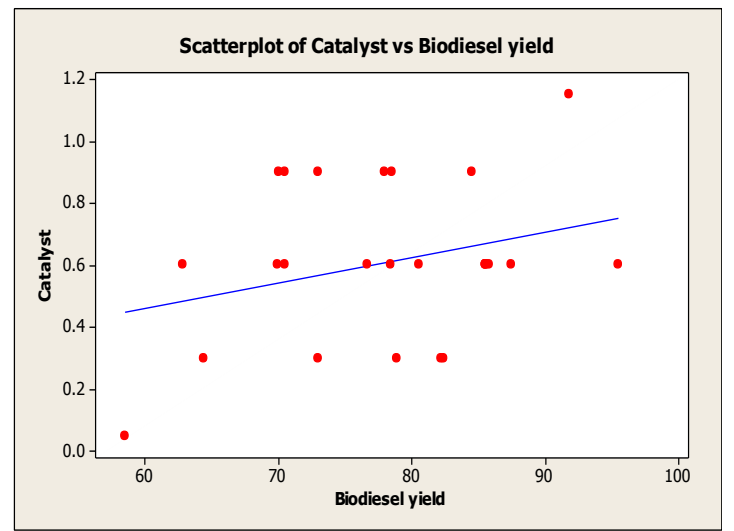

Figure 5. The relation between catalyst concentration and yield

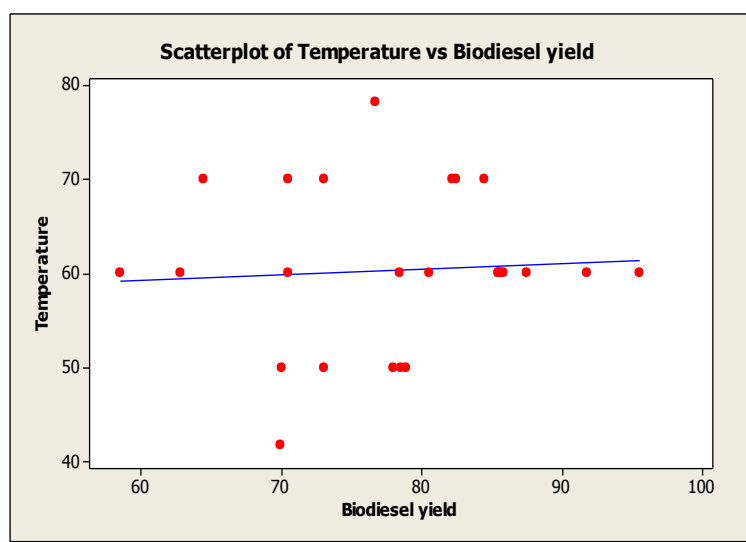

Figure 6. The relation between reaction temperature and yield

\section{Effect of Reaction Time}

Increasing time of reaction has a reverse effect on yield as the high reaction time will lead to drawback reaction reducing the yield and production cost. Low reaction time is not sufficient for the molecules to collide so it will decrease produced biodiesel. Fig 7 shows that the optimum reaction time value is between 1-3 hours. Table 4 the effect of reaction time is an insignificant factor for the reaction compared with other factors as $p$-value is 0.438 . Experiments have reaction time 2 hours or near gives the highest yield.

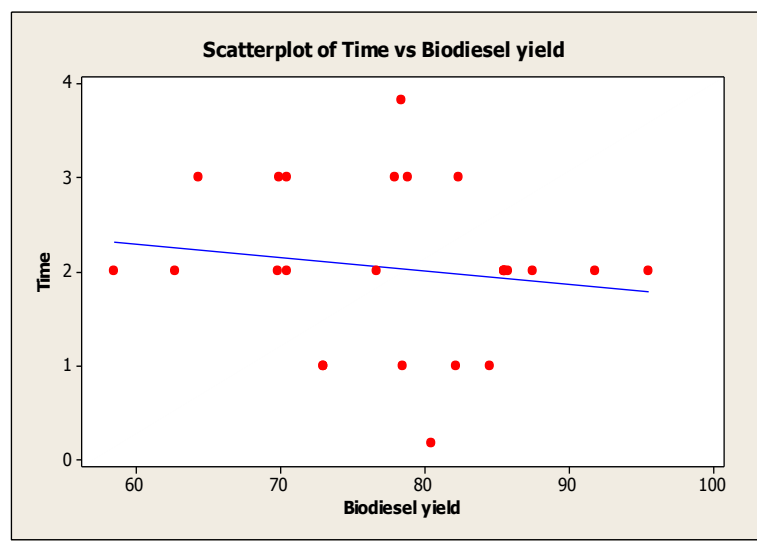

Figure 7. The relation between reaction time and yield

\section{Effect of Mixing Rate}

The optimum Mixing rate ranged from 200 to 400 rpm rate. After this value, the reaction is drawn back and lead to lower yield. Fig 8shows that the yield is slightly inversely proportional to mixing. Mixing rate effect is insignificant factor as shown in table 4 in comparison with other factors.

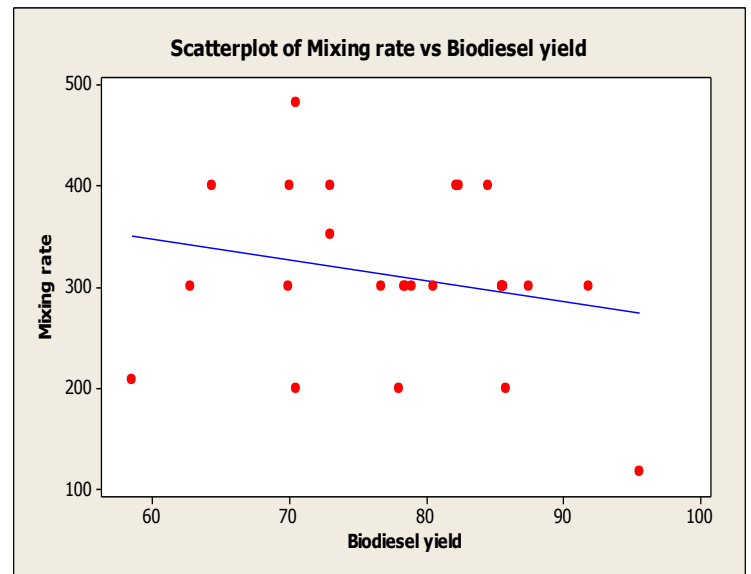

Figure 8. The relation between mixing rate and yield

\section{Biodiesel Standard Properties}

The quality of biodiesel fuel is decided by successful usage in vehicles engines and substitution of non-renewable fossil fuels. The quality of biodiesel has to be applicable to the appropriate standard values. The following table 5 describes all fuel properties related to mentioned runs and this specification according to ASTM D-6751 achieving perfect fuel properties [19-23]. 
Table 5: produced biodiesel specification

\begin{tabular}{|c|c|c|c|c|c|}
\hline $\begin{array}{c}\text { Properti } \\
\text { es }\end{array}$ & Units & Ref & $\begin{array}{l}\text { Limit } \\
\mathrm{s}\end{array}$ & $\begin{array}{c}\text { Run } \\
2\end{array}$ & $\begin{array}{c}\text { Run } \\
8\end{array}$ \\
\hline Yield & gm & --- & & 91.6 & 95.5 \\
\hline Density & $\begin{array}{c}\mathrm{g} / \mathrm{cm} \\
\mathbf{3}\end{array}$ & $\begin{array}{c}\text { AST } \\
\text { M } \\
\text { D405 } \\
2 \\
\end{array}$ & 0.88 & 0.897 & $\begin{array}{c}0.898 \\
1\end{array}$ \\
\hline $\begin{array}{l}\text { Cetane } \\
\text { Number }\end{array}$ & - & $\begin{array}{c}\text { AST } \\
M \\
\text { D613 }\end{array}$ & $\begin{array}{c}48- \\
65\end{array}$ & 49 & 61 \\
\hline $\begin{array}{c}\text { Kinemat } \\
\text { ic } \\
\text { viscosit } \\
y \\
\end{array}$ & cst & $\begin{array}{c}\text { AST } \\
\text { M } \\
\text { D445 }\end{array}$ & $\begin{array}{c}1.9- \\
6\end{array}$ & 4.9 & 5 \\
\hline $\begin{array}{c}\text { Specific } \\
\text { gravity }\end{array}$ & & & & $\begin{array}{c}0.897 \\
9 \\
\end{array}$ & 0.899 \\
\hline FFA & $\%$ & $\begin{array}{c}\text { AST } \\
\text { M } \\
\text { D658 } \\
4 \\
\end{array}$ & $\begin{array}{l}0.42 \\
\max \end{array}$ & 0.084 & 0.084 \\
\hline $\begin{array}{c}\text { Acid } \\
\text { number }\end{array}$ & $\begin{array}{c}\mathrm{mg} \\
\mathrm{KOH} / \\
\mathrm{g}\end{array}$ & $\begin{array}{c}\text { AST } \\
\text { M } \\
\text { D664 }\end{array}$ & $\begin{array}{c}0.8 \\
\max \end{array}$ & 0.168 & 0.168 \\
\hline $\begin{array}{l}\text { Flash } \\
\text { point }\end{array}$ & ${ }^{\circ} \mathrm{C}$ & $\begin{array}{c}\text { AST } \\
\text { M } \\
\text { D93 }\end{array}$ & $\begin{array}{l}120- \\
191\end{array}$ & 129 & 128 \\
\hline $\begin{array}{c}\text { Aniline } \\
\text { Point }\end{array}$ & ${ }^{\circ} \mathrm{C}$ & $\begin{array}{c}\text { AST } \\
M \\
\text { D611 }\end{array}$ & -- & 88.5 & 91 \\
\hline $\begin{array}{l}\text { Cloud } \\
\text { Point }\end{array}$ & ${ }^{\circ} \mathrm{C}$ & $\begin{array}{c}\text { AST } \\
\text { M } \\
\text { D250 } \\
0 \\
\end{array}$ & $\begin{array}{c}-3 \text { to } \\
12\end{array}$ & -4 & -4 \\
\hline $\begin{array}{l}\text { Pour } \\
\text { Point }\end{array}$ & ${ }^{\circ} \mathrm{C}$ & $\begin{array}{c}\text { AST } \\
\text { M } \\
\text { D97 }\end{array}$ & $\begin{array}{c}-15 \\
\text { to } \\
10 \\
\end{array}$ & -6 & -6 \\
\hline $\begin{array}{l}\text { Diesel } \\
\text { Index }\end{array}$ & - & $\begin{array}{c}\text { AST } \\
\text { M } \\
\text { D613 } \\
\end{array}$ & -- & 49.91 & 50.71 \\
\hline API & - & --- & -- & $\begin{array}{r}26 . \\
09\end{array}$ & 25.9 \\
\hline $\begin{array}{c}\text { Calorific } \\
\text { value }\end{array}$ & $\begin{array}{c}\text { Meg } \\
\text { a } \\
\text { joule } \\
/ \mathrm{kg}\end{array}$ & $\begin{array}{c}\text { AST } \\
\text { M } \\
\text { D675 } \\
1 \\
\end{array}$ & 37.3 & 39.8 & 38.5 \\
\hline
\end{tabular}

\section{Conclusion}

The first part of work investigates the optimum conditions to produce high yield of biodiesel in addition the best fuel quality by using factorial design method. The experiments were carried out in the following conditions: reaction temperature from 40 to $78 \mathrm{C}$, reaction time from $1 \mathrm{hr}$ to $3 \mathrm{hrs}$; catalyst concentration from $0.05 \%$ to $1.15 \%$ by weight of used cooking oil; methanol to oil molar ratio from $3: 1$ to 11:1, mixing rate from 200 to $400 \mathrm{rpm}$. The linear regression analysis concluded that methanol to oil ratio and catalyst concentration have a high positive statistical significant effect. Temperature has a positive statistical effect. The process time had a nonstatistical effect on the biodiesel yield and the mixing rate had a negative statistical effect. The best methyl ester conversion obtained was $99.2 \mathrm{wt} . \%$ based on the following conditions : methanol to oil molar ratio of $7.54: 1$, catalyst concentration of $0.875 \%, 1.17 \mathrm{hr}$ of reaction time, temperature of $52{ }^{\circ} \mathrm{C}$, mixing rate 266 rpm. The produced biodiesel can be used in compression ignition engine as its quality is agreeing the American standard testing method (ASTM) and all properties such as Cetane number, acid number, flash point, pour point, cloud point, aniline point, pour point are in the standard range. The calorific value of produced biodiesel is $39.6 \mathrm{MJ} / \mathrm{kg}$ higher than the standard biodiesel calorific value by $6 \%$. The properties of produced biodiesel qualifies its utilization in vehicles instead of petro-diesel especially that the biodiesel is free of any sulfur.

\section{Reference}

[1] Elgharbawy, A.S.A.A., cost analysis for biodiesel production from waste cooking oil plant in Egypt. International Journal of Smart Grid-ijSmartGrid, 2017. 1(1): p. 16-25.

[2] Albahri, T., M. Riazi, and A. Alqattan, Analysis of quality of the petroleum fuels. Energy \& fuels, 2003. 17(3): p. 689-693.

[3] Fernández-Álvarez, P., Vila, J., Garrido, J. M., Grifoll, M., Feijoo, G., \& Lema, J. M. (2007). Evaluation of biodiesel as bioremediation agent for the treatment of the shore affected by the heavy oil spill of the Prestige. Journal of hazardous materials, 147(3), 914922.

[4] Bajaj, A., Lohan, P., Jha, P. N., \& Mehrotra, R. (2010). Biodiesel production through lipase catalyzed transesterification: an overview. Journal of Molecular Catalysis B: Enzymatic, 62(1), 9-14.

[5] Center, A.F.D. Diesel Vehicles Using Biodiesel. 2013; Available from:

https://afdc.energy.gov/vehicles/diesel.html.

[6] Dabelstein, W., Reglitzky, A., Schütze, A., Reders, K., \& Brunner, A. (2000). Automotive fuels. Ullmann's Encyclopedia of Industrial Chemistry, 1-41.

[7] Atabani, A. E., Silitonga, A. S., Badruddin, I. A., Mahlia, T. M. I., Masjuki, H. H., \& Mekhilef, S. (2012). A comprehensive review on biodiesel as an alternative energy resource and its characteristics. Renewable and sustainable energy reviews, 16(4), 2070-2093.

[8] Thaiyasuit, P., K. Pianthong, and I. Worapun, Acid esterification-alkaline transesterification process for methyl ester production from crude rubber seed oil. Journal of oleo science, 2012. 61(2): p. 81-88.

[9] Al-Sakkari, E. G., El-Sheltawy, S. T., Soliman, A., \& Ismail, I. (2018). Transesterification of Low FFA Waste Vegetable Oil using Homogeneous Base Catalyst for Biodiesel Production: Optimization, Kinetics and Product Stability. Journal of Advanced Chemical Sciences, 586-592.

[10] Freedman, B., R.O. Butterfield, and E.H. Pryde, Transesterification kinetics of soybean oil 1. Journal of the American Oil Chemists' Society, 1986. 63(10): p. 1375-1380.

[11] Guo, F., Peng, Z. G., Dai, J. Y., \& Xiu, Z. L. (2010). Calcined sodium silicate as solid base catalyst for biodiesel production. Fuel Processing Technology, 91(3), 322-328. 
[12] Kusdiana, D. and S. Saka, Kinetics of transesterification in rapeseed oil to biodiesel fuel as treated in supercritical methanol. Fuel, 2001. 80(5): p. 693-698.

[13] Alptekin, E., M. Canakci, and H. Sanli. Methyl ester production from chicken fat with high FFA. in World

[14] Renewable Energy Congress-Sweden; 8-13 May; 2011;

[15] Linköping; Sweden. 2011. Linköping University Electronic Press.

[16] Jaber, R., Shirazi, M. M. A., Toufaily, J., Hamieh, A. T., Noureddin, A., Ghanavati, H., ... \& Tabatabaei, M. (2015). Biodiesel wash-water reuse using microfiltration: toward zero-discharge strategy for cleaner and economized biodiesel production. Biofuel Research Journal, 2(1), 148-151.

[17] Goff, M. J., Bauer, N. S., Lopes, S., Sutterlin, W. R., \& Suppes, G. J. (2004). Acid-catalyzed alcoholysis of soybean oil. Journal of the American Oil Chemists' Society, 81(4), 415-420.

[18] El-Gendy, N. S., El-Gharabawy, A. A. S. A., Amr, S. S., \& Ashour, F. H. (2015). Response surface optimization of an alkaline transesterification of waste cooking oil. Int. J. ChemTech Res, 8(8), 385-398.

[19] Xiao, Y., G. Xiao, and A. Varma, A universal procedure for crude glycerol purification from different feedstocks in biodiesel production: experimental and simulation study. Industrial \& engineering chemistry research, 2013. 52(39): p. 14291-14296.

[20] Dooley, S., Won, S. H., Chaos, M., Heyne, J., Ju, Y., Dryer, F. L., ... \& Santoro, R. J. (2010). A jet fuel surrogate formulated by real fuel properties. Combustion and flame, 157(12), 23332339.

[21] Atadashi, I., M.K. Aroua, and A.A. Aziz, High quality biodiesel and its diesel engine application: a review. Renewable and Sustainable Energy Reviews, 2010. 14(7): p. 1999-2008.

[22] Atadashi, I. M., Aroua, M. K., Aziz, A. A., \& Sulaiman, N. M. N. (2012). Production of biodiesel using high free fatty acid feedstocks. Renewable and sustainable energy reviews, 16(5), 3275-3285.

[23] Atadashi, I. M., Aroua, M. K., Aziz, A. A., \& Sulaiman, N. M. N. (2011). Refining technologies for the purification of crude biodiesel. Applied energy, 88(12), 4239-4251.

[24] Elgharbawy, A. S., Sadik, W. A., Sadek, O. M., \& Kasaby, M. A. Glycerolysis treatment to enhance biodiesel production from low-quality feedstocks. Fuel, 284, 118970.

[25] Elgharbawy, A. and A. Sayed, A review on natural gas previous, current and forecasting prices and demand. Journal of Petroleum and Mining Engineering, 2020. 22(1): p. 61-64. 